\title{
The Coupling Effect Research of Ash Deposition and Condensation in Low Temperature Flue Gas
}

\author{
Lei Ma, ${ }^{1,2}$ Feng-zhong Sun, ${ }^{1}$ Zhi-min Li, ${ }^{1}$ Pei Chen, ${ }^{2}$ and Fei Li ${ }^{3}$ \\ ${ }^{1}$ School of Energy \& Power Engineering, Shandong University, Jinan 250061, China \\ ${ }^{2}$ Jinan Institute of Measurement and Testing, Jinan 250002, China \\ ${ }^{3}$ College of Physics Science \& Technology, Jinan University, Jinan 250022, China
}

Correspondence should be addressed to Feng-zhong Sun; sfzh@sdu.edu.cn

Received 5 March 2016; Accepted 11 April 2016

Academic Editor: Jingchao Zhang

Copyright (C) 2016 Lei Ma et al. This is an open access article distributed under the Creative Commons Attribution License, which permits unrestricted use, distribution, and reproduction in any medium, provided the original work is properly cited.

\begin{abstract}
Ash deposition is a key factor that deteriorates the heat transfer performance and leads to higher energy consumption of low pressure economizer working in low temperature flue gas. In order to study the ash deposition of heat exchange tubes in low temperature flue gas, two experiments are carried out with different types of heat exchange tubes in different flue gas environments. In this paper, Nusselt Number $\mathrm{Nu}$ and fouling factor $\varepsilon$ are calculated to describe the heat transfer characteristics so as to study the ash deposition condition. The scanning electron microscope (SEM) is used for the analysis of ash samples obtained from the outer wall of heat exchange tubes. The dynamic process of ash deposition is studied under different temperatures of outer wall. The results showed that ash deposition of heat exchanger will achieve a stable state in constant flue gas environment. According to the condition of condensation of acid vapor and water vapor, the process of ash deposition can be distinguished as mere ash deposition, acid-ash coupling deposition, and acid-water-ash coupling deposition.
\end{abstract}

\section{Introduction}

Since many countries, such as China and India, are still heavily dependent on coal-based energy supply $[1,2]$ and the use of fossil fuels leads to environmental problems, which influences human health and ecosystems sustainability [3], it is of great significance to improve efficiency of coal-fired power plants $[4,5]$.

Ash deposition is a key factor that deteriorates the heat transfer performance and leads to higher energy consumption and inefficiency in usually used industrial heat exchangers [6, 7]. Many researchers paid their attentions to this field. Shi et al. [8] carried out an experiment in a $75 \mathrm{t} / \mathrm{h}$ circulating fluidized bed boiler unit, employing fouling factor $\varepsilon$ and overall heat transfer coefficient ratio $\psi$ to evaluate the influence of ash deposition on heat transfer. Shimogori et al. [9] evaluated the effect of fine ash particles and alkali metals on the decreasing heat flux at the initial stages of ash deposition which had a significant effect on heat transfer characteristics during the whole ash deposition process. Y.J. Kim and S.-S. Kim [10] investigated deposition of particles onto a cold circular cylindrical surface in high temperature particle-laden cross-flows experimentally, obtaining local particle deposition efficiency for two Reynolds number and three wall/gas temperature ratio parameters by using scanning electron microscopy (SEM) techniques. Barroso et al. [11] used an entrained flow reactor to characterize the slagging behaviour of twelve coals/blends under different experimental conditions and perform a detailed characterization of the coals, fly ashes, and deposits. Vuthaluru and French [12] undertook a mineralogical study in order to understand deposit formation in the air heater sections of the boiler through collecting and analyzing several air heater deposit samples in the selected regions of the air heater along with samples of the feed coal, bottom ash, and fly ash for comparison of ash chemistry and mineralogy. Yan et al. [13] demonstrated the implications of three coalescence schemes (i.e., the no-coalescence, the full-coalescence, and a partial 


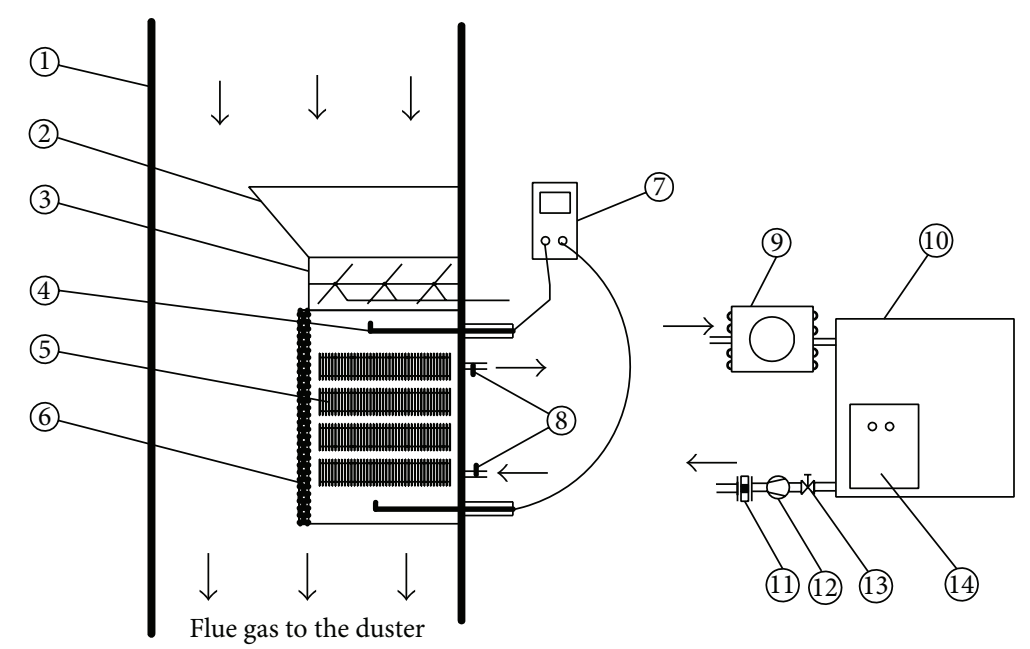
(1) Flue pipe
(2) Expanding section
(3) Rectification section
(4) Pitot
(5) Finned tube bundles
(6) Thermal insulation layer
(7) Differential-pressure gauge
(8) Resistance thermometer
(9) Radiator
(10) Water tank
(11) Flowmeter
(12) Pump
(13) Valve
(14) Controller

Figure 1: Experimental system I.

coalescence) on ash character and subsequent ash deposition by means of an ash formation model and an ash deposition model.

The temperature of the outer wall of heat exchange tubes is a factor that can influence ash deposition, since extremely low temperature may cause sulfuric acid vapor and water vapor contained in the flue gas to condense on the outer wall of tubes to form liquid film, resulting in serious ash deposition and corrosion. Li et al. [14] conducted experiments to investigate heat transfer characteristics of heat exchanger in the flue gas environment with dust and acid and proposed the definition of engineering dew point of flue gas by analyzing the differences of heat transfer characteristics under different temperatures of outer wall, illustrating that heat transfer characteristics of heat exchanger can be influenced by outer wall temperatures. Nuntaphan and Kiatsiriroat [15] investigated the effect of fly-ash deposit on thermal performance of a cross-flow heat exchanger having a set of spiral finned tubes as a heat transfer surface, with the inlet temperature of cold water stream being kept constant at $5^{\circ} \mathrm{C}$. Wang et al. [16] performed ash deposition experiments with anti-dew point corrosion materials at temperature below dew point and analyzed microstructures of the composition of ash deposition by X-ray diffraction (XRD) and Energy Dispersive Spectrometer (EDS), illustrating that the ash deposition layer could be divided into noncondensation zone, main condensation zone, and secondary condensation zone. He et al. [17] performed a three-dimensional numerical study on acid condensation characteristics of H-type finned tube bank with 10 rows of tubes, which led to a conclusion that, among seven influence factors studied, Reynolds number and fin thickness have the most important effect on the average condensation rate on the fin surface. Meanwhile, the study on dew point, at which temperature the sulfuric acid vapor or water vapor begins to condense, has received a lot of interest. Bahadori [18] formulated a predictive tool to estimate the acid dew point, for sulfur in various fuels, volume fraction in gas up to 0.10 (0.10 mass fraction in liquid), excess air fractions up to 0.25 , and elemental concentrations of carbon up to 3 .

It should be noted from the above discussions, to the authors' knowledge, that few field experiments have been conducted on the coupling effect of acid-ash or acid-waterash on ash deposition. Therefore, the aim of this work is to investigate the ash deposition and heat transfer characteristics of heat exchange tubes in low temperature flue gas. Two experiments are carried out in different environment, with different types of heat exchange tubes and with different data processing methods in order to make the conclusion universal.

\section{Material and Methods}

2.1. Experimental System. Figure 1 shows the schematic diagram of the experimental system I. The system mainly includes experimental section installed in the flue pipe of a fluidized bed combustion boiler (CFB) and a thermostatic water tank for providing constant temperature water. In the experiment, the flue gas flows through expanding section, rectification section, and tube bundles of $\mathrm{H}$-type elliptical finned tubes in in-line arrangement and stagger arrangement. 


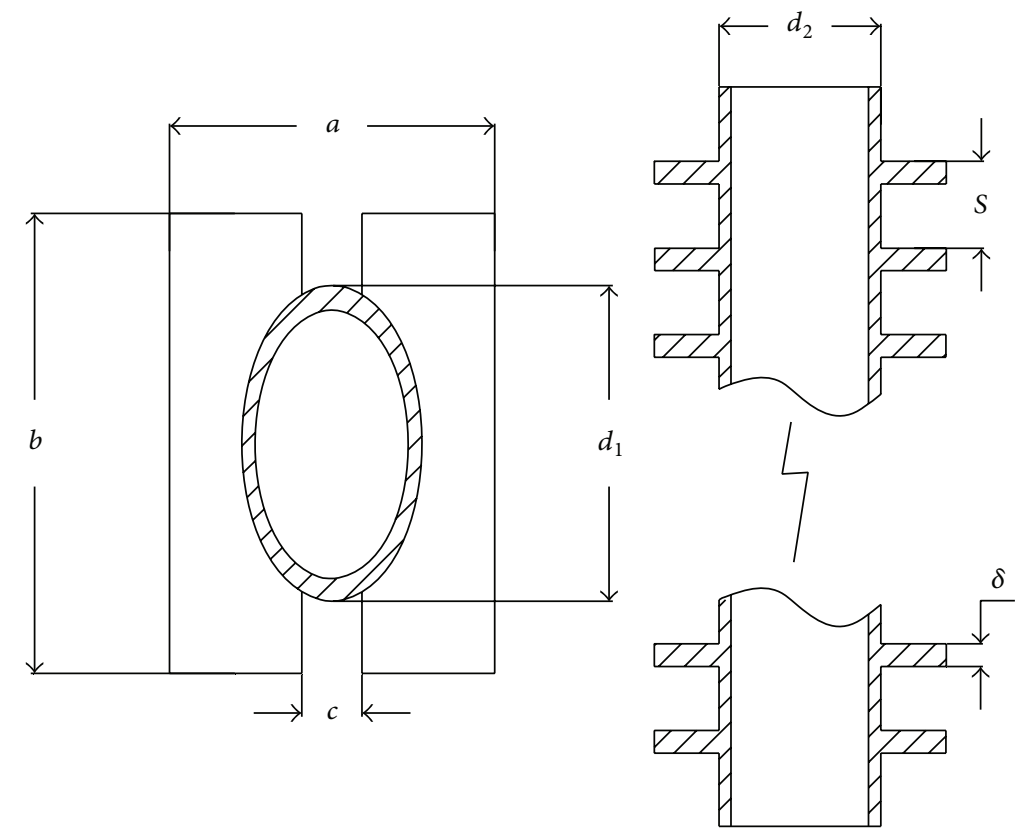

FIGURE 2: Geometrical sketch of the tube of experiment I.

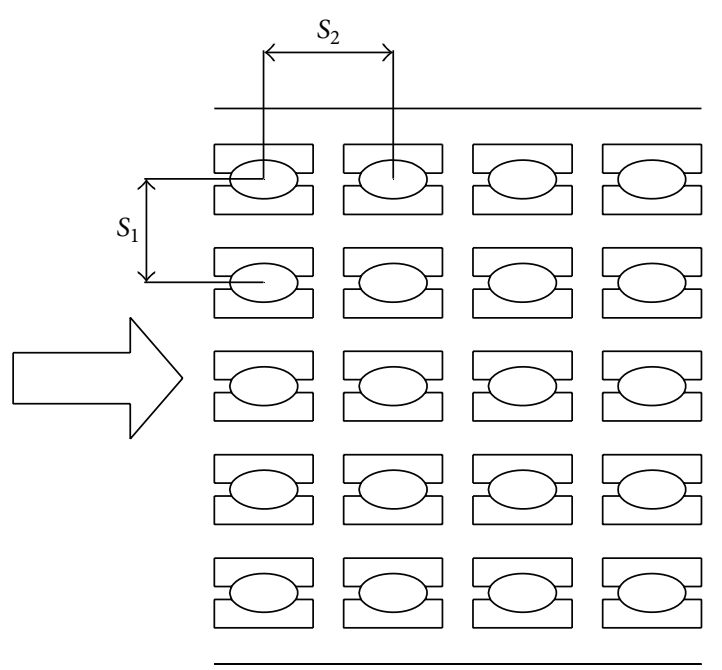

(a) In-line arrangement

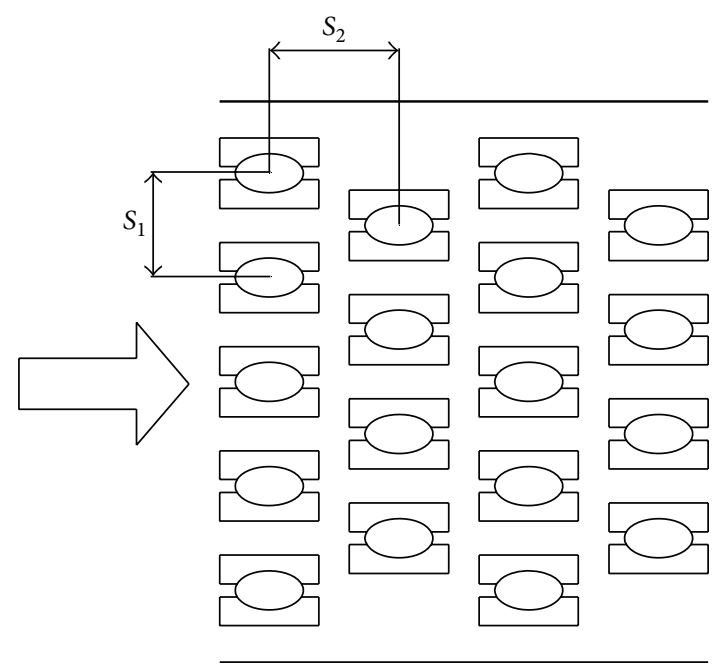

(b) Stagger arrangement

Figure 3: Different arrangements of tube bundles in experiment I.

Figure 2 shows the geometrical sketch of the H-style elliptical finned tube of experiment I. Figure 3 shows different arrangements of tube bundles in experiment I.

The main technique specification of experiment $\mathrm{I}$ is shown in Table 1 . The geometric parameters of finned tube bundles are listed in Table 2.

Figure 4 shows the schematic diagram of experimental system II. Compared with experimental system I, the finned tube bundles are replaced by a double pipe and the experimental environment is changed. Figure 5 shows the geometrical sketch of double pipe of experiment II.
The main technique specification of experiment II is shown in Table 3 . The geometric parameters of double pipe are listed in Table 4.

In experiment I, constant temperature water (i.e., desalted water) is supplied by a thermostatic water tank to the heat exchange tubes, the outlet water is cooled by a radiator and utilized cyclically, the flow rate of the flue gas is adjusted by a shutter and measured by cross-section method using pitots and differential-pressure gauge, the flow rate of constant temperature water is controlled by a valve in inlet pipe and measured by a flowmeter, and the temperatures of water 


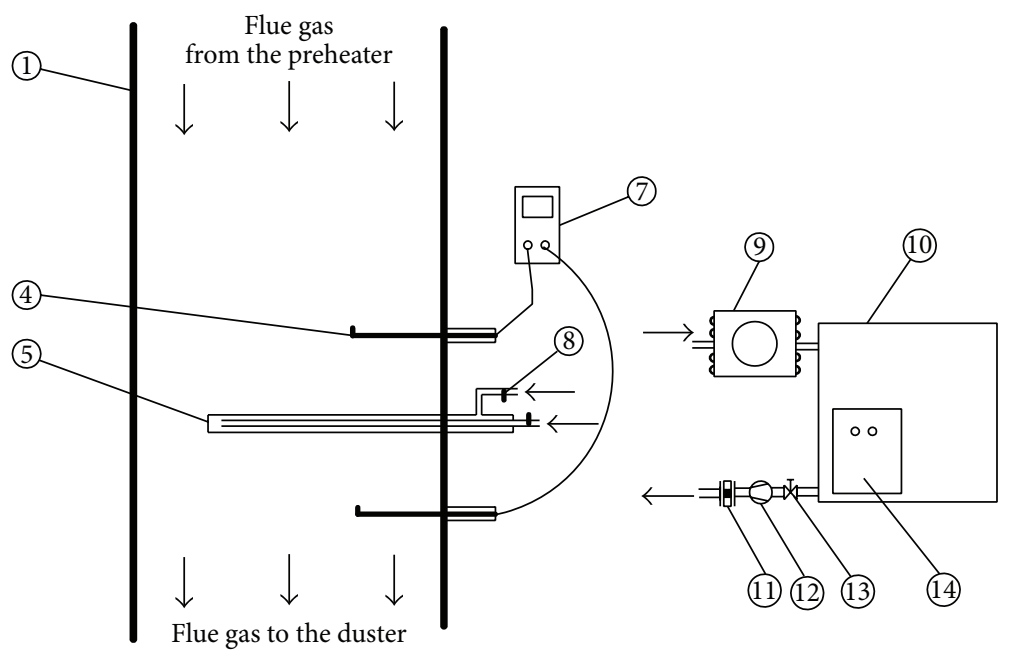
(1) Flue pipe
(10) Water tank
(4) Pitot
(11) Flowmeter
(5) Double pipe
(12) Pump
(7) Differential-pressure gauge
(13) Valve
(8) Resistance thermometer
(14) Controller
(9) Radiator

FIGURE 4: Experimental system II.

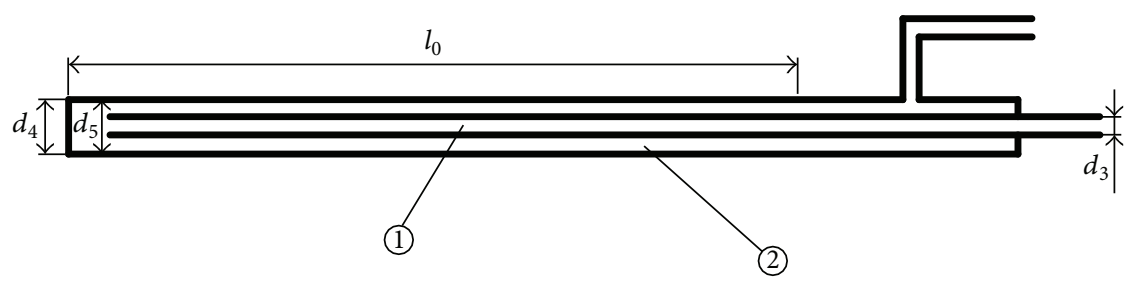

(1) Inner pipe

(2) Outer pipe

FIGURE 5: Geometrical sketch of the double pipe of experiment II.

TABLE 1: Main technique specification of the CFB and industrial analysis data of coal of experiment I.

\begin{tabular}{lc}
\hline Technique specification & Value \\
\hline Specified evaporation rate $(\mathrm{t} / \mathrm{h})$ & 75 \\
Nominal steam pressure $(\mathrm{MPa})$ & 3.82 \\
Steam temperature $\left({ }^{\circ} \mathrm{C}\right)$ & 450 \\
Exhaust gas temperature $\left({ }^{\circ} \mathrm{C}\right)$ & 150 \\
Thermal efficiency $(\%)$ & 85 \\
Coal fineness $(\mathrm{mm})$ & $\leq 13$ \\
Ash content $(\%)$ & 21 \\
Volatile content $(\%)$ & 26 \\
Total moisture $(\%)$ & 18.08 \\
Air-dried moisture $(\%)$ & 8.34 \\
\hline
\end{tabular}

inlet and outlet are measured by resistance thermometers. Meanwhile, the mass flow of constant temperature water and qualitative temperature is kept constant. In experiment
TABLE 2: Geometric parameters of finned tube bundles of experiment I.

\begin{tabular}{lc}
\hline Geometric parameters & Value \\
\hline Fin length $a(\mathrm{~mm})$ & 54 \\
Fin width $b(\mathrm{~mm})$ & 76.5 \\
Slit width $c(\mathrm{~mm})$ & 10 \\
Long axis diameter $d_{1}(\mathrm{~mm})$ & 52.46 \\
Short axis diameter $d_{2}(\mathrm{~mm})$ & 30 \\
Fin thickness $\delta(\mathrm{mm})$ & 1.5 \\
Fin pitch $S(\mathrm{~mm})$ & 13.5 \\
Traversal pitch $S_{1}(\mathrm{~mm})$ & 80 \\
Longitudinal pitch $S_{2}(\mathrm{~mm})$ & 100 \\
Relative traversal distance 1 & 2.105 \\
Relative longitudinal distance 2 & 2.632 \\
\hline
\end{tabular}

II, the measuring instruments used are the same as that in experiment I. Measuring instruments and the precision thereof are shown in Table 5. 
TABLE 3: Technique specification of the boiler and industrial analysis data of coal of experiment II.

\begin{tabular}{lc}
\hline Technique specification & Value \\
\hline Rated load $(\mathrm{MW})$ & 300 \\
Nominal steam pressure $(\mathrm{MPa})$ & 20.75 \\
Steam temperature $\left({ }^{\circ} \mathrm{C}\right)$ & 565.5 \\
Exhaust gas temperature $\left({ }^{\circ} \mathrm{C}\right)$ & 131.1 \\
$\mathrm{SO}_{2}$ content before desulfurization $\left(\mathrm{mg} / \mathrm{m}^{3}\right)$ & 1840 \\
Total moisture $(\%)$ & 12.74 \\
Air-dried moisture $(\%)$ & 6.07 \\
Air-dried ash $(\%)$ & 17.73 \\
Air-dried volatile content $(\%)$ & 27.28 \\
Fixed carbon content $(\%)$ & 48.69 \\
Higher heating value $(\mathrm{KJ} / \mathrm{Kg})$ & 24856 \\
Net calorific value $(\mathrm{KJ} / \mathrm{Kg})$ & 22138 \\
Total sulfur $(\%)$ & 0.795 \\
\hline
\end{tabular}

TABLE 4: Geometric parameters of double pipe of experiment II.

\begin{tabular}{lc}
\hline Item & Value \\
\hline Total length $L(\mathrm{~mm})$ & 1400 \\
Effective length $l_{0}(\mathrm{~mm})$ & 1000 \\
Outer diameter of outer pipe $d_{4}(\mathrm{~mm})$ & 38 \\
Inner diameter of outer pipe $d_{5}(\mathrm{~mm})$ & 36 \\
Thickness of outer pipe $\delta_{0}(\mathrm{~mm})$ & 1 \\
Outer diameter of inner pipe $d_{3}(\mathrm{~mm})$ & 20 \\
Thickness of inner pipe $\delta_{i}(\mathrm{~mm})$ & 1 \\
\hline
\end{tabular}

TABLE 5: Measuring instruments.

\begin{tabular}{|c|c|c|c|c|}
\hline & Quantity & Unit & Type & Precision \\
\hline $\begin{array}{l}\text { Differential- } \\
\text { pressure } \\
\text { gauge }\end{array}$ & 1 & $\mathrm{~Pa}$ & Testo512 & 0.1 \\
\hline $\begin{array}{l}\text { Resistance } \\
\text { thermometer }\end{array}$ & 6 & ${ }^{\circ} \mathrm{C}$ & PT100 & 0.1 \\
\hline Pitot & 4 & $\mathrm{~Pa}$ & & 1 \\
\hline Flowmeter & 2 & $\mathrm{M}^{3} \cdot \mathrm{s}^{-1}$ & LZJ-6F & 2.5 \\
\hline Data acquisition & 1 & & HP-34970A & \\
\hline Flue gas analyzer & 1 & & NOVA2000 & \\
\hline
\end{tabular}

2.2. Experiment. The preparations of experiment I include installing the experimental instruments into the flue pipe, closing the shutter to keep the heat exchange surface clean, waiting for the boiler running steadily, heating the water in the tank, and opening the pump and valve to pump the constant temperature water into the heat exchanger continuously.

In experiment $I$, the experimental procedure is as follows: opening the shutter, controlling the temperature of water inlet using thermostatic water tank so that the wanted temperature of outer wall of heat exchange tubes is obtained, waiting for the ash deposition achieving stable state, recording the parameters to be measured, adjusting the shutter many times to obtain data under different flue gas velocities, and lowering the temperature of water inlet to obtain another group of parameters under another temperature of outer wall.

In experiment II, the experimental procedure is basically the same as that of experiment I, except the following differences: firstly, shutter 3 is removed and the flow rate of flue gas is constant, so the procedure of adjusting shutter 3 is omitted; secondly, the temperatures of inlet water, outlet water, and outer wall are recorded in real time; thirdly, once the ash deposition achieves stable state, the double pipe is brought out of the flue pipe to be observed and is cleaned up before it is put back.

2.3. Data Process of Experiment I. In experiment I, dimensionless criterion Nusselt Number $\mathrm{Nu}$ is used to describe the heat transfer characteristics.

Reynolds Number Re of flue gas outside tubes can be calculated by

$$
\operatorname{Re}=\frac{w \times d_{2}}{v_{g}},
$$

where $w$ refers to velocity of flue gas, $\mathrm{m} \cdot \mathrm{s}^{-1}, d_{2}$ refers to short axis diameter of elliptical tube, $\mathrm{m}$, and $v_{g}$ refers to kinematic viscosity of flue gas, $\mathrm{m}^{2} \cdot \mathrm{s}^{-1}$.

In experiment I, finned tubes are well ribbed with compact heat exchange surface, and the temperature difference between water inlet and outlet is limited within $5^{\circ} \mathrm{C}$ by controlling the flow rate of constant temperature water. Hence, the temperature distribution on the surface of outer wall is uniform. In order to avoid disturbing the temperature distribution around the surface of outer wall due to the arrangement of too many resistance thermometers, the heat transfer coefficient $h$ is calculated using variable separation approach without measuring the temperature of outer wall directly. To be specific, the outer wall heat transfer coefficient $h_{w}$ is calculated firstly by the measured parameters and then handled dimensionlessly to obtain the fitting formula of $\mathrm{Nu}$.

According to heat transfer theory, it holds that

$$
\frac{1}{K}=\frac{1}{h_{w}}+\beta\left(\frac{1}{h_{i}}+r_{m}+r_{f}\right),
$$

where $K$ refers to overall heat transfer coefficient, $\mathrm{W} \cdot \mathrm{m}^{-2} \cdot \mathrm{K}^{-1}$, $h_{w}$ refers to heat transfer coefficient outside tube wall, $\mathrm{W} \cdot \mathrm{m}^{-2} \cdot \mathrm{K}^{-1}, \beta$ refers to finned coefficient, $h_{i}$ refers to convective heat transfer coefficient of inner wall, $\mathrm{W} \cdot \mathrm{m}^{-2} \cdot \mathrm{K}^{-1}$, $r_{m}$ refers to thermal resistance of tube wall, $\mathrm{m}^{2} \cdot \mathrm{K} \cdot \mathrm{W}^{-1}$, and $r_{f}$ refers to thermal resistance of fouling on inner wall, $\mathrm{m}^{2} \cdot \mathrm{K} \cdot \mathrm{W}^{-1}$.

In the experiment, $h_{w}$ is much smaller than $h_{i}$, so $\beta\left(1 / h_{i}+\right.$ $\left.r_{m}+r_{f}\right)$ keeps invariant, which can be defined as $R$. Then the heat transfer coefficient outside tube wall $h_{w}$ can be written as follows:

$$
h_{w}=\frac{1}{(1 / K-R)} .
$$

Dimensionless criterion number $\mathrm{Nu}$ can be obtained by

$$
\mathrm{Nu}=\frac{h_{w} \times d_{2}}{\lambda_{g}}
$$


where $d_{2}$ refers to short axis diameter of elliptical tube, $\mathrm{m}$, and $\lambda_{g}$ refers to thermal conductivity of flue gas, $\mathrm{W} \cdot \mathrm{m}^{-1} \cdot \mathrm{K}^{-1}$.

2.4. Data Process of Experiment II. In experiment II, another data processing method is used. Fouling factor $\varepsilon$ is calculated to describe the ash deposition condition.

First, total heat exchange $Q$ is calculated according to temperature difference between inlet water and outlet water:

$$
Q=c m\left(T_{\text {out }}-T_{\text {in }}\right),
$$

where $Q$ refers to total heat exchange per unit time, W, $c$ refers to specific heat capacity of water, $\mathrm{J} \cdot \mathrm{kg}^{-1} \cdot{ }^{\circ} \mathrm{C}^{-1}, m$ refers to mass flow of constant temperature water, $\mathrm{kg} \cdot \mathrm{s}^{-1}$, and $T_{\text {out }}$ and $T_{\text {in }}$ refer to temperature of outlet water and inlet water, respectively, ${ }^{\circ} \mathrm{C}$.

Then, overall heat transfer coefficient $K$ can be calculated by

$$
K=\frac{Q}{F\left(T_{g}-T_{o}\right)},
$$

where $F=\pi \times d_{4} \times l_{0}, F$ refers to effective heat exchange area of double pipe, $\mathrm{m}^{2}, d_{4}$ refers to outer diameter of outer pipe, $\mathrm{m}, l_{0}$ refers to effective length of double pipe, $\mathrm{m}, K$ refers to overall heat transfer coefficient, $\mathrm{W} \cdot \mathrm{m}^{-20} \mathrm{C}^{-1}, K$ refers to total heat exchange per unit time, $\mathrm{W}$, and $T_{g}$ and $T_{o}$ refer to temperature of flue gas and the outer wall of double pipe, respectively, ${ }^{\circ} \mathrm{C}$.

Since the heat transfer of double pipe with ash deposited can be considered as heat transfer of multilayer medium, overall heat transfer coefficient $K$ can also be calculated by

$$
\begin{aligned}
K & =\frac{1}{\left(1 / h_{i}+\delta_{s} / \lambda_{s}+\delta_{m} / \lambda_{m}+1 / h_{o}\right)+\delta_{f} / \lambda_{f}} \\
& =\frac{1}{1 / K_{0}+\varepsilon},
\end{aligned}
$$

where $K$ refers to overall heat transfer coefficient, $\mathrm{W} \cdot \mathrm{m}^{-2} \cdot \mathrm{K}^{-1}$, $K_{0}$ refers to overall heat transfer coefficient of clean double pipe, $\mathrm{W} \cdot \mathrm{m}^{-2} \cdot \mathrm{K}^{-1}, h_{i}$ refers to convective heat transfer coefficient between inner wall and water, $\mathrm{W} \cdot \mathrm{m}^{-2} \cdot \mathrm{K}^{-1}, h_{o}$ refers to convective heat transfer coefficient between outer wall and flue gas, $\mathrm{W} \cdot \mathrm{m}^{-2} \cdot \mathrm{K}^{-1}, \delta_{s}, \delta_{m}$, and $\delta_{f}$ refer to thickness of scale on inner wall, outer tube, and fouling on outer wall, respectively, $\mathrm{m}, \lambda_{s}, \lambda_{m}$, and $\lambda_{f}$ refer to thermal conductivity of scale on inner wall, outer tube, and fouling on outer wall, respectively, $\mathrm{W} \cdot \mathrm{m}^{-1} \cdot \mathrm{K}^{-1}$, and $\varepsilon$ refers to fouling factor, $\mathrm{m}^{2} \cdot \mathrm{KW}^{-1}$.

According to (6) and (7), $\varepsilon$ can be calculated by

$$
\varepsilon=\frac{1}{K}-\frac{1}{K_{0}}
$$

where $\varepsilon$ refers to fouling factor, $\mathrm{m}^{2} \cdot \mathrm{K} \mathrm{W}^{-1}, K$ refers to overall heat transfer coefficient, $\mathrm{W} \cdot \mathrm{m}^{-2} \cdot \mathrm{K}^{-1}$, and $K_{0}$ refers to overall heat transfer coefficient of clean double pipe, $\mathrm{W} \cdot \mathrm{m}^{-2} \cdot \mathrm{K}^{-1}$.

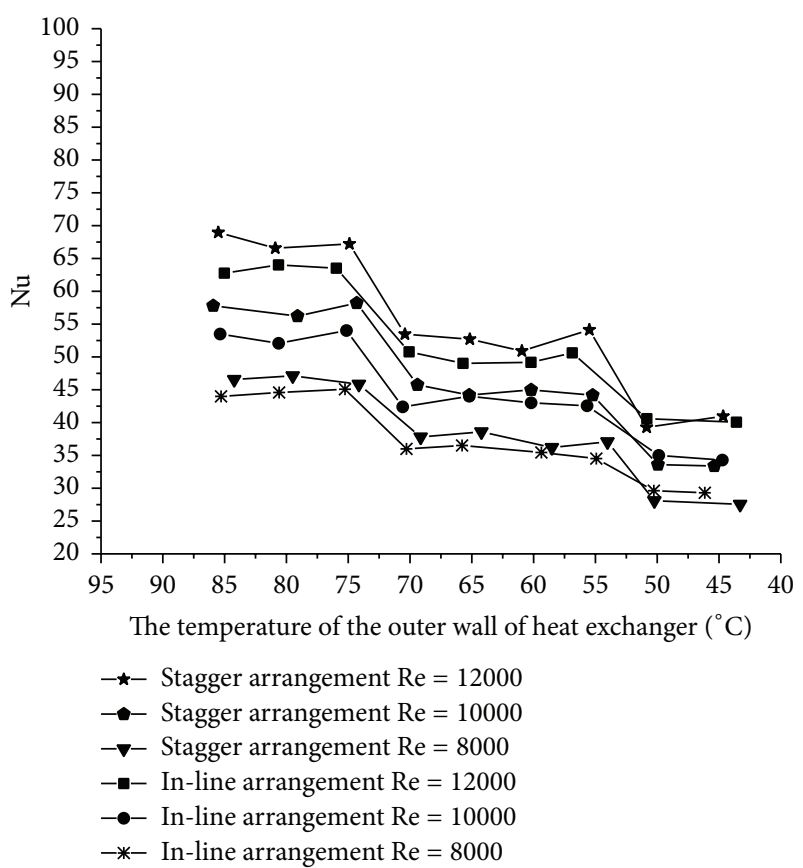

FIgURE 6: Changing regulation of $\mathrm{Nu}$ with respect to the temperature of outer wall in experiment I.

2.5. Error Analysis. The directly measured parameters in the experiment and the error thereof are shown in Table 5. The errors of indirectly measured parameters, such as dimensionless heat transfer coefficient and fouling factor, are obtained by combining standard uncertainties, according to

$$
\begin{aligned}
\Delta Y & =\left\{\left(\frac{\partial Y}{\partial x_{1}} \Delta x_{1}\right)^{2}+\left(\frac{\partial Y}{\partial x_{2}} \Delta x_{2}\right)^{2}+\cdots\right. \\
& \left.+\left(\frac{\partial Y}{\partial x_{3}} \Delta x_{3}\right)^{2}\right\}^{1 / 2} .
\end{aligned}
$$

In this experiment, the combined standard uncertainties of $\mathrm{Nu}$ and $\varepsilon$ obtained by (6) are $2.94 \%$ and $1.73 \%$, respectively.

\section{Results and Discussion}

3.1. Results and Discussion of Experiment I. In experiment I, $\mathrm{Nu}$ is calculated to indicate heat transfer characteristic of tubes. As can be seen from Figure 6, Nu of tubes in different flow field with different $\mathrm{Eu}$ of flow gas with different arrangement shows same change regulation according to the change of temperature of outer wall. That is, Nu reduces sharply at two turning points, accompanied with three temperature ranges in which heat transfer is stable.

At the beginning stage, the heat exchanger works at a mere ash deposition condition and the ash deposition reaches a state of equilibrium, and the deposition rate is equal to the denudation rate. When the temperature of outer wall reduces to $70^{\circ} \mathrm{C}$, the equilibrium is destroyed and Nu reduces rapidly. This is because acid vapor starts to condense on the outer wall, changing the viscosity of ash deposited on the tube, 


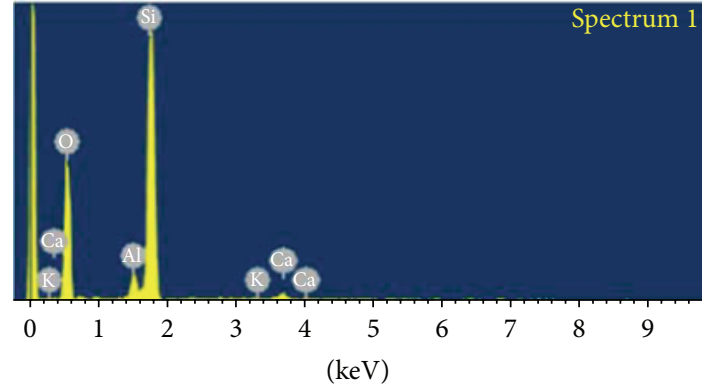

Full scale 1482 cts cursor: 0.000

(a) $80^{\circ} \mathrm{C}$

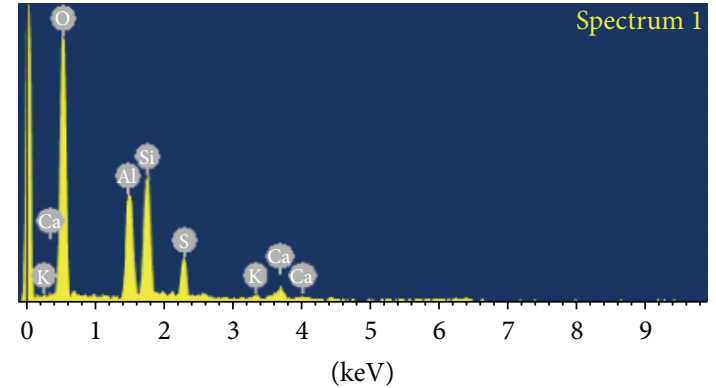

Full scale 837 cts cursor: 0.000

(b) $65^{\circ} \mathrm{C}$

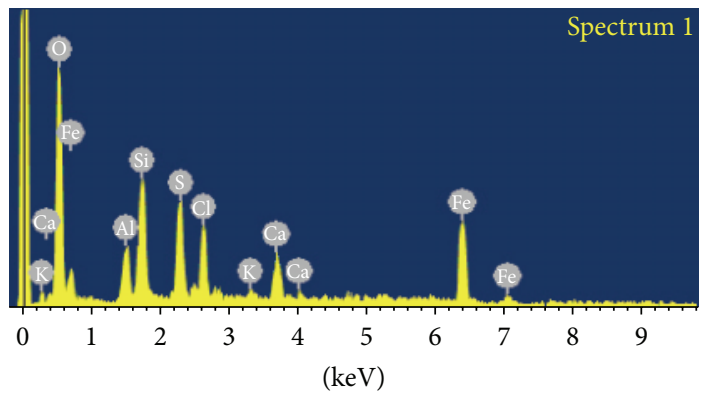

Full scale 293 cts cursor: 0.000

(c) $45^{\circ} \mathrm{C}$

FIGURE 7: The energy spectrum diagrams of the ash particles under different wall temperatures.

so the deposition rate becomes greater than the denudation rate. After hours of acid-ash coupling deposition process, a new equilibrium is established and the heat exchanger works in a steady state again. The new balance cannot be stuck by lowering the temperature of outer wall unless the temperature reaches $50^{\circ} \mathrm{C}$. Under this temperature, the water vapor starts to condense on the outer wall, which aggravates ash deposition and causes a rapid decrease of $\mathrm{Nu}$. Finally, a new balance establishes and the heat exchanger works in steady acid-water-ash coupling deposition condition.

Ash samples collected from surfaces of tubes in different ash deposition conditions are studied by energy spectrum analysis method using SU-70 thermal field SEM. The energy spectrum diagrams of the ash particles under different wall temperatures are shown in Figure 7 and a semiquantitative assessment can be obtained.

As can be seen in the figure, no acid condenses on the outer wall when temperature of the wall is $80^{\circ} \mathrm{C}$. When the temperature of outer wall is $65^{\circ} \mathrm{C}$, the main elements of ash deposited on the outer wall are $\mathrm{O}, \mathrm{Si}, \mathrm{Al}, \mathrm{S}, \mathrm{Ca}$, and $\mathrm{K}$, ordered in mass content. Under this temperature, a little element $S$ appears in deposited ash, illustrating that the acid vapor begins to condense on the surface of the exchanger. When the temperature of outer wall comes down to $45^{\circ} \mathrm{C}$, which is below water dew point, the main elements of ash deposited on the outer wall are $\mathrm{O}, \mathrm{Si}, \mathrm{S}, \mathrm{Cl}, \mathrm{Fe}, \mathrm{Al}, \mathrm{Ca}$, and $\mathrm{K}$, ordered in mass content. That means large amount of acid vapor and water vapor begins to condense on the surface of the heat exchanger and corrodes the surface severely with the oxygen in flue gas.
Based on the above observation and analysis, during the process of lowering the temperature of outer wall of heat exchanger, the ash deposition can be divided into three stages: mere ash deposition condition, acid-ash coupling deposition condition, and acid-water-ash coupling deposition condition. In each stage, the ash deposition will reach a stable state after hours and Nu will keep constant in the stable state.

3.2. Results and Discussion of Experiment II. In experiment II, fouling factor $\varepsilon$ is calculated to describe the ash deposition condition. As can be seen from Figure 8, with the fall of temperature, $\varepsilon$ of double pipe increases obviously at $70^{\circ} \mathrm{C}$ and $45^{\circ} \mathrm{C}$. This is consistent with the phenomenon of experiment I.

In order to study the dynamic process of ash deposition, the real-time curve of $\varepsilon$ under typical temperature of outer wall is discussed. Figure 9 shows the real-time change of $\varepsilon$ when the temperatures of outer wall are $41^{\circ} \mathrm{C}, 65^{\circ} \mathrm{C}$, and $71^{\circ} \mathrm{C}$. As can be seen, $\varepsilon$ achieves a stable value after about 2-3 hours, independent of the temperature of outer wall. At $71^{\circ} \mathrm{C}, \varepsilon$ stabilized on about $0.002 \mathrm{~m}^{2} \cdot \mathrm{K} / \mathrm{W}$, at $65^{\circ} \mathrm{C}, \varepsilon$ stabilized on about $0.005 \mathrm{~m}^{2} \cdot \mathrm{K} / \mathrm{W}$, and at $41^{\circ} \mathrm{C}, \varepsilon$ stabilized on about $0.008 \mathrm{~m}^{2} \cdot \mathrm{K} / \mathrm{W}$.

After hours of ash deposition, the double pipe is brought out of the flue pipe and the deposition condition is observed. When the temperature is $71^{\circ} \mathrm{C}$, there is no ash deposited on the windward side; the ash deposited on the leeward side is dry and can be blown away. When the temperature is $65^{\circ} \mathrm{C}$, there is no ash deposited on the windward side; the ash 


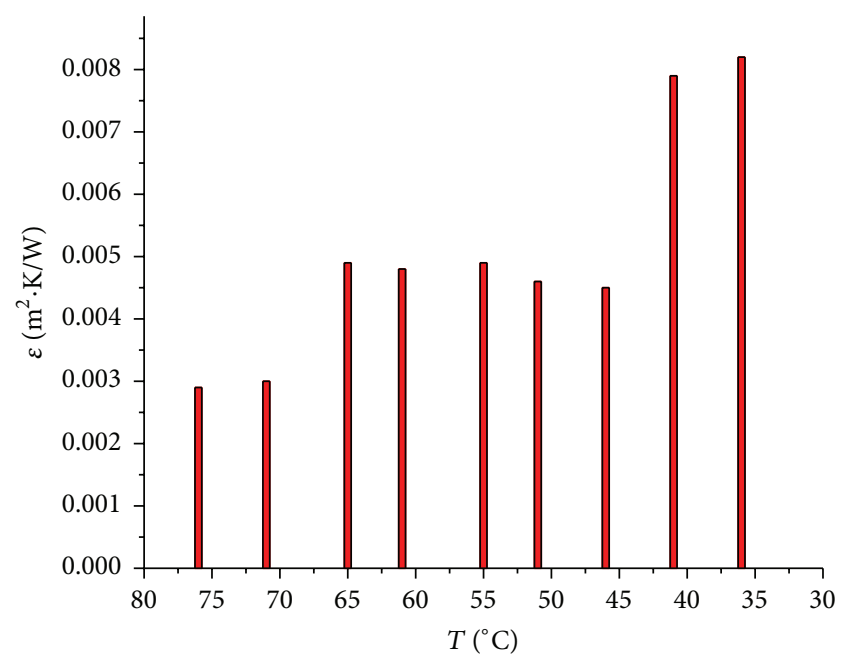

FIGURE 8: Changing regulation of $\varepsilon$ with respect to the temperature of outer wall in experiment II.

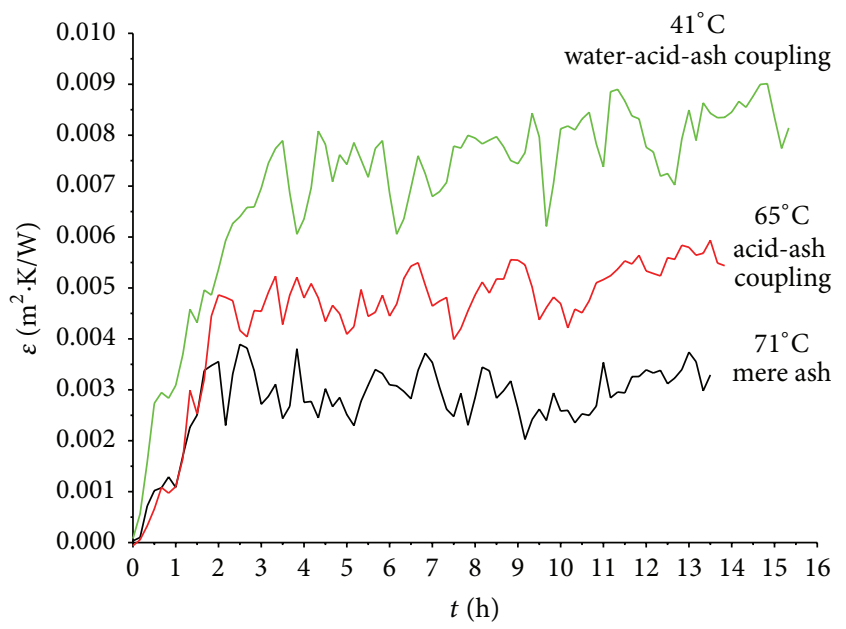

FIGURE 9: Real-time curve of $\varepsilon$ under typical temperature of outer wall.

deposited on the leeward side is a little wet, which cannot be blown away but can be mopped by a cloth. When the temperature is $41^{\circ} \mathrm{C}$, wet ash deposited on both windward side and leeward side and can only be removed by using sandpaper or knife. This is because when the temperature is $65^{\circ} \mathrm{C}$, acid vapor starts to condense on the outer wall, and when the temperature is $41^{\circ} \mathrm{C}$, large amount of acid vapor and water vapor condenses on the outer wall. Pictures of ash deposited on the outer wall of double pipe are shown in Figure 10.

\section{Conclusions}

In this paper, two experiments are carried out using different heat exchangers in different flue gas environments. The following conclusions can be demonstrated:

(1) Ash deposition of exchanger in low temperature flue gas is influenced by acid condensation and water condensation.

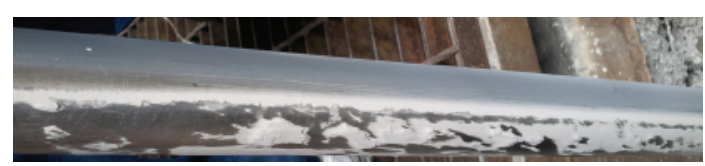

(a) $71^{\circ} \mathrm{C}$

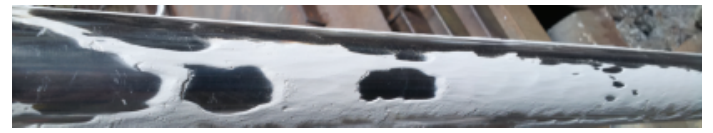

(b) $65^{\circ} \mathrm{C}$

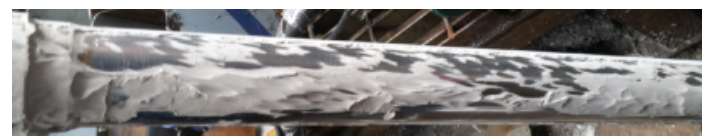

(c) $41^{\circ} \mathrm{C}$

FIGURE 10: Ash deposited on the outer wall of double pipe.

(2) In constant flue gas environment, heat transfer characteristic of heat exchanger will achieve a stable state after a period of time.

(3) According to the temperature of outer wall of heat exchanger, the ash deposition can be divided into three stages: mere ash deposition condition, acidash coupling deposition condition, and acid-waterash coupling deposition condition.

\section{Nomenclature}

$K$ : Overall heat transfer coefficient $\left(\mathrm{W} / \mathrm{m}^{2 \circ} \mathrm{C}\right)$

$r$ : Thermal resistance $\left(\mathrm{m}^{2 \circ} \mathrm{C} / \mathrm{W}\right)$

$h$ : Heat transfer coefficient $\left(\mathrm{W} / \mathrm{m}^{2 \circ} \mathrm{C}\right)$

$w$ : Flue gas velocity at minimum cross section $(\mathrm{m} / \mathrm{s})$

Q: Heat exchange per unit time (W)

$F$ : Effective heat exchange area of double pipe $\left(\mathrm{m}^{2}\right)$

T: Temperature $\left({ }^{\circ} \mathrm{C}\right)$

c: Specific heat capacity of water $\left(\mathrm{J} / \mathrm{kg}^{\circ} \mathrm{C}\right)$

$d$ : Diameter $(\mathrm{m})$

$m$ : Mass flow $(\mathrm{kg} / \mathrm{s})$

$l$ : Effective heat exchange length of double pipe (m).

Greek

$\alpha$ : Coefficient of convective heat transfer $\left(\mathrm{W} / \mathrm{m}^{2 \circ} \mathrm{C}\right)$

$\beta$ : Finned coefficient

$\delta$ : Thickness (m)

$\lambda$ : Thermal conductivity $\left(\mathrm{W} / \mathrm{m}^{\circ} \mathrm{C}\right)$

$\rho$ : Density $\left(\mathrm{kg} / \mathrm{m}^{3}\right)$

$v$ : Kinematic viscosity

$\varepsilon$ : Fouling factor.

\section{Subscripts}

$o$ : Outer wall of tube

$i$ : Inner wall of tube

$w$ : Outside of tube

in: Inlet water

out: Outlet water 
g: Gas side

$m$ : Tube wall

$f$ : Fouling on outer wall

$s$ : Scale on inner wall.

\section{Competing Interests}

The authors declare that there is no conflict of interests regarding the publication of this paper.

\section{Acknowledgments}

The work was supported in part by Shandong Province Natural Science Foundation (ZR2015EQ022).

\section{References}

[1] Y. Yang, C. Xu, G. Xu, Y. Han, Y. Fang, and D. Zhang, "A new conceptual cold-end design of boilers for coal-fired power plants with waste heat recovery," Energy Conversion and Management, vol. 89, pp. 137-146, 2015.

[2] C.-F. You and X. C. Xu, "Coal combustion and its pollution control in China," Energy, vol. 35, no. 11, pp. 4467-4472, 2010.

[3] F. Vélez, F. Chejne, G. Antolin, and A. Quijano, "Theoretical analysis of a transcritical power cycle for power generation from waste energy at low temperature heat source," Energy Conversion and Management, vol. 60, pp. 188-195, 2012.

[4] V.-D. Stevanovic, T. Wala, S. Muszynski, M. Milic, and M. Jovanovic, "Efficiency and power upgrade by an additional high pressure economizer installation at an aged 620 MWe lignitefired power plant," Energy, vol. 66, no. 1, pp. 907-918, 2014.

[5] Y. Suzukawa, S. Sugiyama, Y. Hino, M. Ishioka, and I. Mori, "Heat transfer improvement and $\mathrm{NO}_{x}$ reduction by highly preheated air combustion," Energy Conversion and Management, vol. 38, no. 10-13, pp. 1061-1071, 1997.

[6] N. S. Harding and D. C. O'Connor, "Ash deposition impacts in the power industry," Fuel Processing Technology, vol. 88, no. 1112, pp. 1082-1093, 2007.

[7] A. Herz, M. R. Malayeri, and H. Müller-Steinhagen, "Fouling of roughened stainless steel surfaces during convective heat transfer to aqueous solutions," Energy Conversion and Management, vol. 49, no. 11, pp. 3381-3386, 2008.

[8] Y.-T. Shi, M. Gao, G.-H. Tang, F.-Z. Sun, and W.-Q. Tao, "Experimental research of CFB ash deposition on helical finned tubes," Applied Thermal Engineering, vol. 37, pp. 420-429, 2012.

[9] M. Shimogori, T. Mine, N. Ohyatsu, N. Takarayama, and Y. Matsumura, "Effects of fine ash particles and alkali metals on ash deposition characteristics at the initial stage of ash deposition determined in 1.5 MWth pilot plant tests," Fuel, vol. 97, pp. 233-240, 2012.

[10] Y.-J. Kim and S.-S. Kim, "Experimental study of particle deposition onto a circular cylinder in high-temperature particle-laden flows," Experimental Thermal and Fluid Science, vol. 5, no. 1, pp. 116-123, 1992.

[11] J. Barroso, J. Ballester, L. M. Ferrer, and S. Jiménez, "Study of coal ash deposition in an entrained flow reactor: influence of coal type, blend composition and operating conditions," Fuel Processing Technology, vol. 87, no. 8, pp. 737-752, 2006.

[12] H.-B. Vuthaluru and D.-H. French, "Investigations into the air heater ash deposit formation in large scale pulverised coal fired boiler," Fuel, vol. 140, pp. 27-33, 2015.
[13] L. Yan, R. P. Gupta, and T. F. Wall, "The implication of mineral coalescence behaviour on ash formation and ash deposition during pulverised coal combustion," Fuel, vol. 80, no. 9, pp. 1333-1340, 2001.

[14] F. Li, F. Sun, and Y. Shi, "Hot-state experiment on double-pipe heat exchanger under coupled effect of fouling and acid," CIESC Journal, vol. 65, no. 8, pp. 2876-2881, 2014.

[15] A. Nuntaphan and T. Kiatsiriroat, "Thermal behavior of spiral fin-and-tube heat exchanger having fly ash deposit," Experimental Thermal and Fluid Science, vol. 31, no. 8, pp. 1103-1109, 2007.

[16] Y.-G. Wang, Q.-X. Zhao, Z.-X. Zhang, Z.-C. Zhang, and W.Q. Tao, "Mechanism research on coupling effect between dew point corrosion and ash deposition," Applied Thermal Engineering, vol. 54, no. 1, pp. 102-110, 2013.

[17] Y.-L. He, H. Han, S.-Z. Tang, and T. Zhou, "Sulfuric acid deposition characteristics of H-type finned tube bank with 10 rows," International Journal of Heat and Mass Transfer, vol. 81, pp. 137-141, 2015.

[18] A. Bahadori, "Estimation of combustion flue gas acid dew point during heat recovery and efficiency gain," Applied Thermal Engineering, vol. 31, no. 8-9, pp. 1457-1462, 2011. 


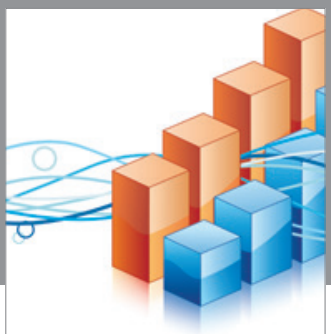

Advances in

Operations Research

vatem alat4

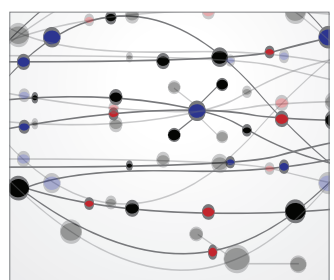

\section{The Scientific} World Journal
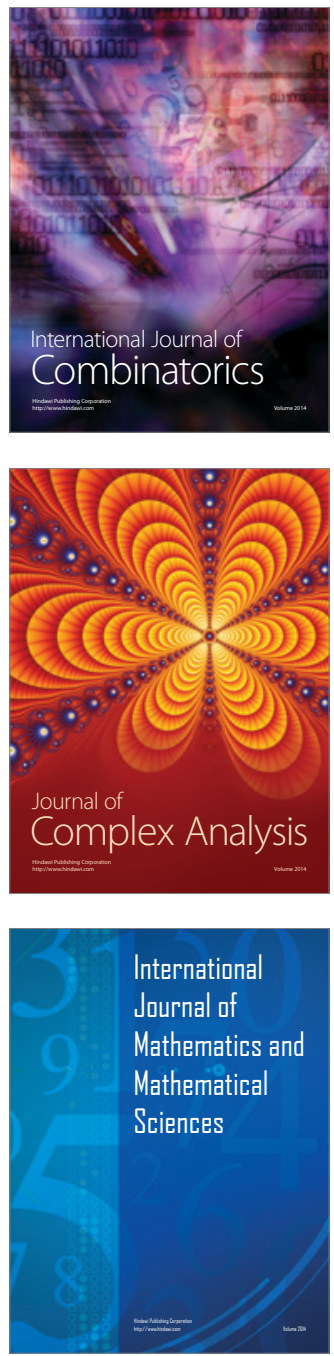
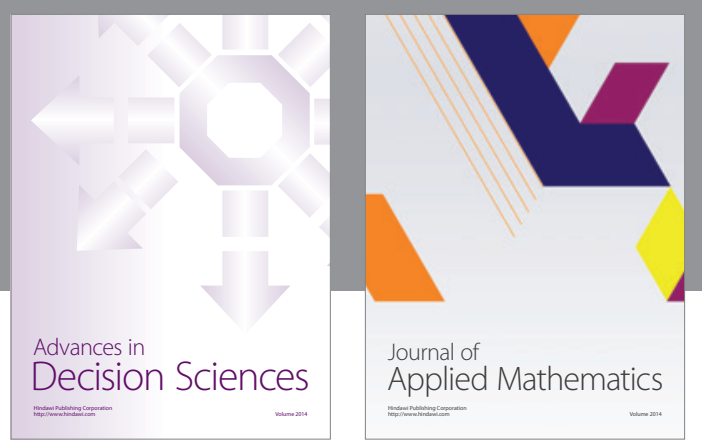

Algebra

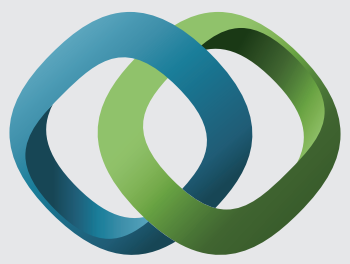

\section{Hindawi}

Submit your manuscripts at

http://www.hindawi.com
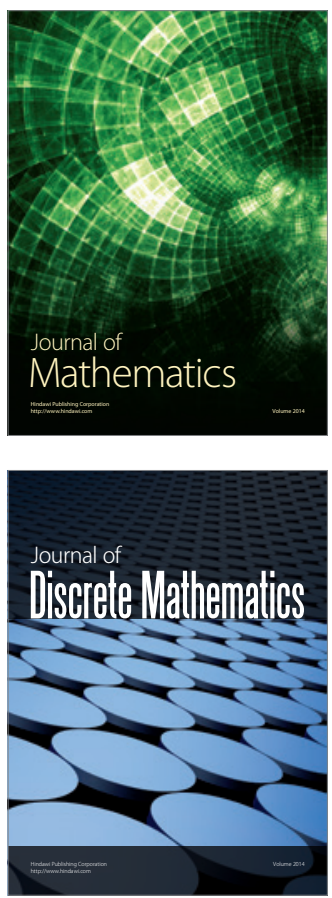

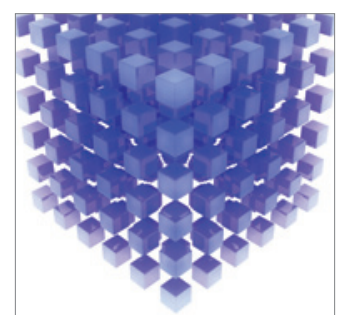

Mathematical Problems in Engineering
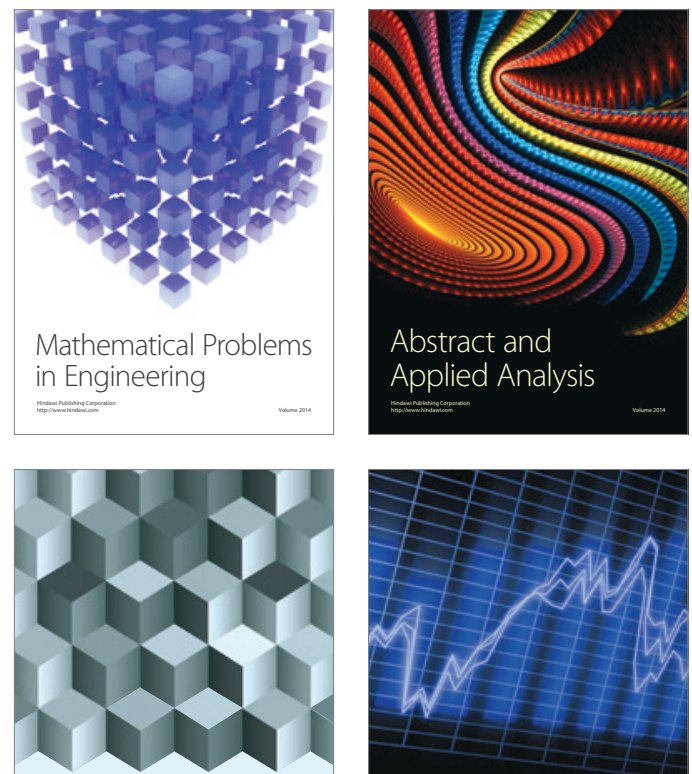

Journal of

Function Spaces

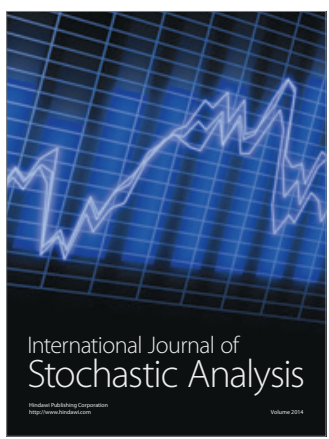

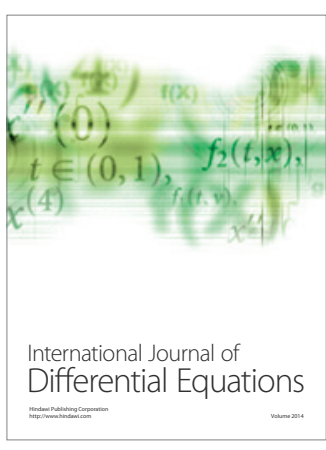
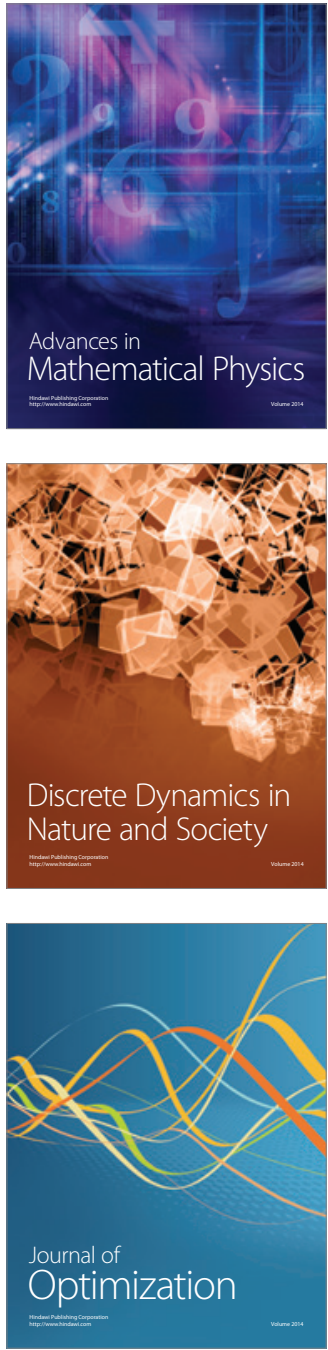